\title{
Electrical Tuning in Hair Cells Isolated from the Chick Cochlea
}

\author{
P. A. Fuchs, T. Nagai, ${ }^{a}$ and M. G. Evans \\ Department of Physiology, University of Colorado Health Sciences Center, Denver, Colorado 80262
}

\begin{abstract}
Tall (inner) hair cells were isolated from specific locations in the chick cochlea. The electrical membrane properties of these cells were recorded using the tight-seal whole-cell technique. Depolarizing currrent steps elicited damped voltage oscillations that ranged in frequency from 100 to 250 $\mathrm{Hz}$ among cells from the middle third of the cochlea (basal cells). The current-voltage relation obtained under voltage clamp was dominated by calcium-activated potassium current in the voltage range over which these oscillations occurred. Tall hair cells isolated from the apical tip of the cochlea (apical cells) exhibited action potentials and lower frequency voltage oscillations $(5-14 \mathrm{~Hz})$ during depolarizing current steps. Outward currents in these cells were 20 -fold slower than those found in the basal cells. These results suggest that electrical tuning of hair cells may play a role in determining the frequency selectivity of the chick cochlea.
\end{abstract}

The frequency range of avian hearing is more restricted than that of mammals (Dooling, 1980); however, over its range, avian frequency selectivity is equal to that of mammals (Sachs et al., 1974), despite the much shorter basilar membrane of birds and its poorly tuned vibration pattern (von Bekesy, 1960; Gummer et al., 1987). It has been suggested that electrical tuning of hair cells might contribute to avian frequency selectivity (Manley, 1979; Manley et al., 1985), as found in turtles (Crawford and Fettiplace, 1981) and frogs (Ashmore, 1983; Lewis and Hudspeth, 1983; Pitchford and Ashmore, 1987). This proposal was based on the occurrence of preferred intervals in the spontaneous activity of cochlear afferent fibers and is supported by their nonlinear phase versus frequency relation (Gleich, 1987) and the pronounced temperature dependence of tuning of cochlear afferents in birds (Schermuly and Klinke, 1985). In the present study we provide direct evidence that hair cells of the chick cochlea have electrical membrane properties similar to those of electrically tuned hair cells in lower vertebrates. Further, the electrical membrane properties of chick hair cells vary as a function of cochlear position and, presumably therefore, with their acoustic frequency selectivity.

The chick cochlea is a curved membranous duct $4-5 \mathrm{~mm}$ in length containing some 10,000 hair cells (Tilney and Tilney, 1986) seated on the basilar membrane (Fig. 1). von Bekesy

\footnotetext{
Received July 9, 1987; revised Oct. 22, 1987; accepted Oct. 26, 1987.

We would like to thank Drs. W. J. Betz, A. R. Martin, S. R. Levinson, and W. O. Wickelgren for comments on earlier drafts of the manuscript. We would also like to thank Ms. L. Stahl and Mr. G. Tarver for their technical assistance. This work was supported in part by Grants BSRG 05357, NS21454, and NS01007 from the National Institutes of Health.

Correspondence should be addressed to P. A. Fuchs at the above address.

a Present address: Department of Physiology, Teikyo University School of Medicine, Tokyo 173, Japan.

Copyright (C) 1988 Society for Neuroscience $0270-6474 / 88 / 072460-08 \$ 02.00 / 0$
}

(1960) established by direct observation of the chick cochlea that as the basilar membrane vibrated at different frequencies, the point of maximal displacement varied from apex to base of the cochlea as frequency increased. Thus, it can be concluded that hair cells in the broad, flexible apex will be subject to lowfrequency vibration, while cells from successively more basal positions will be subject to successively higher frequency vibration. If the electrical properties of the hair cell membrane also play a role in auditory tuning, then such properties ought to vary with location in a similar, tonotopic, manner.

Previous experiments on electrically tuned hair cells in the turtle cochlea demonstrated that the acoustic best frequency and sharpness of tuning could be predicted by the frequency and rate of decay of voltage ringing arising from a step depolarization (Crawford and Fettiplace, 1981). The frequency of voltage ringing was, in turn, correlated with the magnitude and kinetics of a calcium-activated potassium current $\left(K_{\mathrm{Ca}}\right.$ current) recorded under voltage-clamp conditions (Art and Fettiplace, 1987). Similar results have also been obtained in hair cells of the frog (Roberts et al., 1986).

In the following experiments we examined hair cells isolated from the middle of the cochlea ("basal cells") and from the apical tip ("apical cells"). We found that chick hair cells could be electrically resonant and that the kinetics of the dominant outward current were related to the resonant frequency of the cell. A preliminary account of some of these results has been presented in abstract form (Fuchs and Mann, 1986).

\section{Materials and Methods}

Isolation of solitary hair cells from the chick cochlea. Chickens first respond to sound at embryonic day 14 and have essentially adult hearing by $10 \mathrm{~d}$ after hatching (Rubel, 1978). Cochleas were dissected from 2to 6-week posthatch Leghorns of either sex. Following decapitation the skull was split along the sagittal midline and the brain removed. An opening was made around the foramen of the VIIIth nerve, through which the cochlea was removed after careful cutting of surrounding connective tissue. The scala media of the isolated cochlea was opened by cutting away the overlying tegmentum vasculosum. After a $10 \mathrm{~min}$ exposure to $90 \mu \mathrm{g} / \mathrm{ml}$ subtilisin endopeptidase (Sigma, St. Louis) at $23^{\circ} \mathrm{C}$, the gelatinous tectorial membrane overlying the basilar papilla was removed with fine forceps. Subtilisin treatment was followed by $0.5 \mathrm{mg} /$ $\mathrm{ml}$ papain for $20 \mathrm{~min}$ at $30^{\circ} \mathrm{C}$. Both enzymes were dissolved in a lowdivalent saline containing (mM): $154 \mathrm{NaCl}, 6 \mathrm{KCl}, 0.1 \mathrm{CaCl}_{2}, 5 \mathrm{HEPES}$, 8 glucose, and $0.5 \mathrm{mg} / \mathrm{ml} \mathrm{BSA}$. An etched tungsten needle was used to divide the hair cell epithelium into $200-\mu$ m-wide sections (Fig. 1). Each section contained several hundred hair cells, of which approximately $10 \%$ were successfully isolated as solitary cells by transfer to a recording chamber using a fire-polished suction pipette (tip diameter, $30 \mu \mathrm{m}$ ) that had been coated with a silanizing agent (Prosil-28, PCR Inc., Gainesville, FL). The glass coverslip that formed the bottom of the recording chamber was previously cleaned with acid to improve cell adherence. Cells were viewed with a $40 \times$ objective on a Nikon inverted microscope modified for Hoffman differential-interference-contrast optics.

Hair cell morphology in the chick cochlea varies from tall columnar 


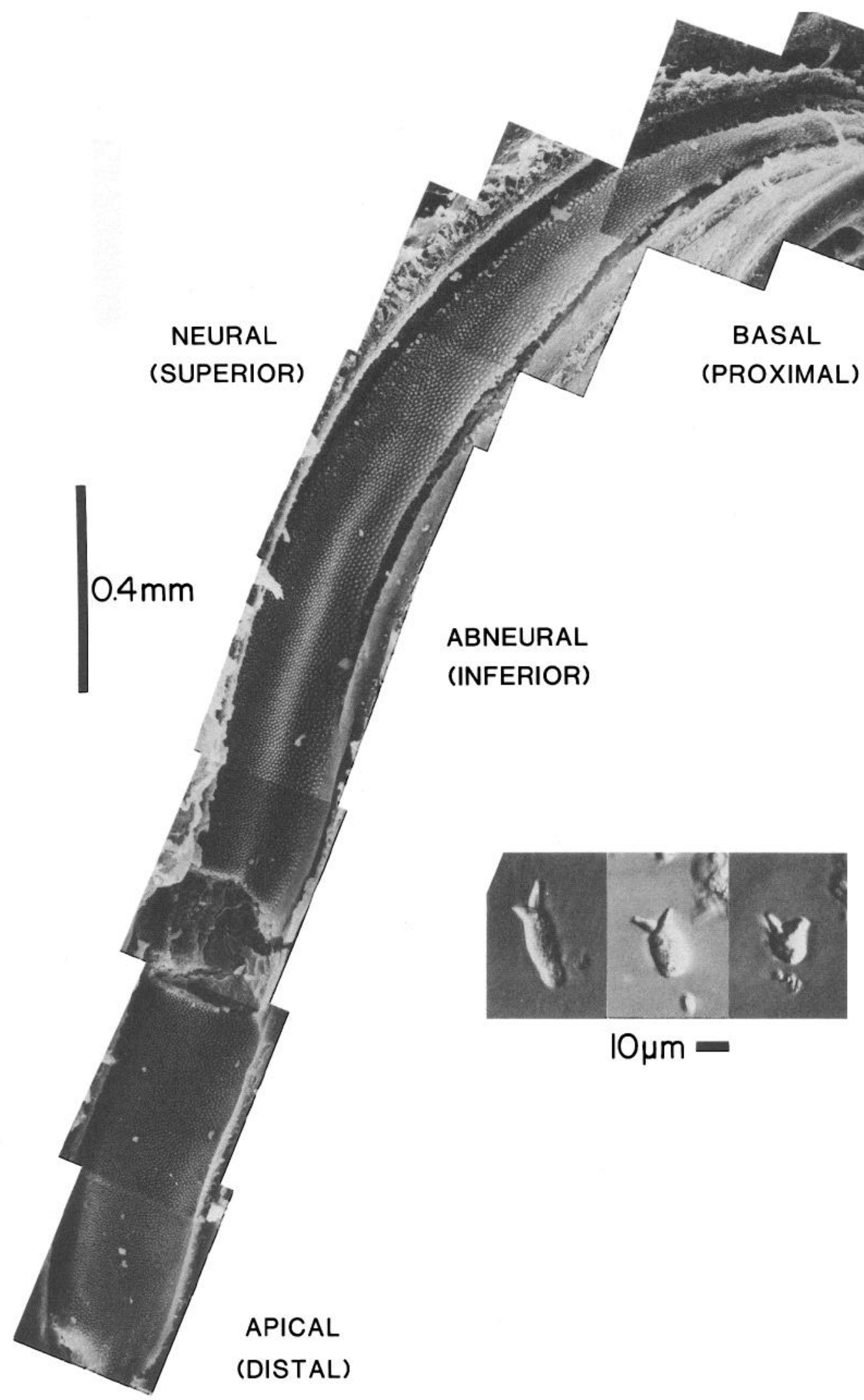

Figure 1. Preparation of single hair cells from discrete regions of the chick cochlea. Following dissection and treatment with proteolytic enzymes, the overlying tectorial membrane of the isolated cochlea was lifted off and a $200-\mu \mathrm{m}$-wide section of hair cells was then removed. The cochlea shown here was then fixed and prepared for scanning electron microscopy. Photographs of individual tall, intermediate, and short hair cells isolated as described from the apical third of different cochleas are shown in the inset. The origin of these cells and the dissected section in the entire cochlea do not correspond to the locations of cells in this study, but serve merely to illustrate the isolation procedure and hair cell morphology. Tall cells come from the neural (superior) edge of the cochlea, corresponding in position to that of inner hair cells in the mammalian cochlea. Short hair cells are found furthest from the neural insertion, over the free basilar membrane, similar in position to that of mammalian outer hair cells. 
cells nearest the neural insertion to much wider, short cells on the abneural edge (Fig. 1, inset) (Hirokawa, 1978; Tanaka and Smith, 1978). All the results presented here are from tall cells that ranged from 15 to $20 \mu \mathrm{m}$ in length.

The yield of tall hair cells was better from apical than from basal sections. This arises in part because there is a greater proportion of short cells in basal sections (Hirokawa, 1978; Tanaka and Smith, 1978). In addition, we observed a degree of damage to inner (tall) hair cells in basal sections in our scanning electron micrographs. This damage consisted of swellings or blebs on the apical surface of the cells, just eccentric to the position of the kinocilium. Such damage would further reduce the yield of basal tall cells. Fortunately, with careful handling this damage could be limited to the basalmost third of the cochlea, and sufficient numbers of tall cells could be found in the apical half of the cochlea if care was taken to visualize and pick up cells lying over the neural limb, where the tall cells were located.

Electrical recording. Recordings from isolated cells were made using tight-seal whole-cell techniques, providing either voltage recording under current clamp or current recording under voltage clamp (Marty and Neher, 1983). Cells were bathed by saline containing (mM): $154 \mathrm{NaCl}$, $6 \mathrm{KCl}, 2.8 \mathrm{MgCl}_{2}, 5.6 \mathrm{CaCl}_{2}$, buffered to $\mathrm{pH} 7.4$ with $5 \mathrm{mM} \mathrm{HEPES} /$ $\mathrm{NaOH}$; in addition, $8 \mathrm{~mm}$ glucose was added. In Ca-free solutions $\mathrm{CaCl}_{2}$ was replaced by an equimolar amount of $\mathrm{MgCl}_{2}$, and $1 \mathrm{mM}$ EGTA was added to the solution.

The recording chamber was superfused continuously with oxygenated saline at room temperature $\left(22-25^{\circ} \mathrm{C}\right)$. Test solutions were applicd by an $80-\mu \mathrm{m}$-wide perfusion tube positioned close to the cell (Yellen, 1982). This method allowed for rapid, reversible application of experimental solutions [outward currents could be blocked by tetra-ethyl ammonium (TEA) within $0.2 \mathrm{sec}]$. Electrodes of 2-5 M $\Omega$ resistance were pulled from borosilicate glass and filled with a solution containing (mM): $112 \mathrm{KCl}$, $2 \mathrm{MgCl}_{2}, 0.1 \mathrm{CaCl}_{2}, 11$ EGTA, 2 ATP, and 10 HEPES buffered to $\mathrm{pH}$ 7.2 with $\mathrm{KOH}$ (final concentration, $30 \mathrm{~mm}$ ). In some experiments, 2 mM EGTA and $1.0 \mathrm{~mm} \mathrm{CaCl}$, were used in the internal solution. No consistent differences in outward currents were found in these cells. $\mathrm{CsCl}$ replaced $\mathrm{KCl}$ in the pipettes in experiments designed to block outward currents. The electrode tips were lightly fire-polished and the shanks coated with Sylgard (Dow Corning Corp., Midland, MI) to reduce capacitance. When possible, the series resistance $(8-25 \mathrm{M} \Omega$ ) was compensated for soon after the intracellular recording was obtained and, in the best cases, resulted in capacitive time constants of $40 \mu \mathrm{sec}$. However, as a result of the brevity of many recordings from basal cells, compensation for series resistance was not always possible and was therefore calculated from the capacitive transient for later arithmetic correction. Under these circumstances the temporal response of the voltage-clamp amplifier was not optimally compensated. However, the small input capacitance of chick hair cells (5-7 pF) ensured that even the slowest time constants $(175 \mu \mathrm{sec})$ were usually brief enough to permit recording of the most rapidly rising outward currents. The faster inward currents were occasionally obscured. Membrane potentials have been corrected for the junction potential between the internal solutions and the external saline. The junction potential was $-4 \mathrm{mV}$ for the $\mathrm{K}$ solution and -3 $\mathrm{mV}$ for the Cs solution. Therefore, under normal recording conditions an observed membrane potential of $-50 \mathrm{mV}$ was in fact $-54 \mathrm{mV}$.

Data were taped on an FM tape recorder (Vetter, model D, Rebersburg, PA), which acted as a low-pass filter $(-3 \mathrm{~dB}$ corner $4.4 \mathrm{kHz})$. Stored dala were analyzed after an experiment using a DEC PDP 11/ $23+$ and the DAOS analysis system (Laboratory Software Associates, Fitzroy, Victoria 3065, Australia).

\section{Results}

\section{Voltage response of basal cells}

We studied the membrane properties of 14 basal cells. Of these, 8 were characterized with respect to both voltage response and the ionic currents observed under voltage clamp. These cells are included in Table 1. Ionic currents were studied under various blocking conditions in another 6 cells.

The average resting potential of basal cells, measured in current clamp, was $-61 \mathrm{mV}$. The resting membrane potential was often very "noisy," with spontaneous fluctuations of several millivolts occurring continuously in some cells. This noise was usually irregular, occasionally sinusoidal, and occurred at a mean frequency that depended on the resting membrane potential. Thus, some cells, which had more negative resting potentials, had little or no voltage noise at rest but became noisy upon depolarization.

We attempted to characterize the transient response of the cell by step injections of current. When the cell was depolarized with a small current step, decaying voltage oscillations (ringing) were observed superimposed on a positive plateau (Fig. $2 A$, upper records). A considerably slower after-hyperpolarization followed the step. Current steps of the oppositc polarity caused much larger changes in membrane potential with no associated oscillations (Fig. 2A, lower record), suggesting a rectifying current-voltage $(I-V)$ relation.

The ringing frequency during the step increased with increasing depolarization. For example, in the cell shown in Figure $2 A$, the average ringing frequency increased from $119 \mathrm{~Hz}$ at -44 $\mathrm{mV}$ to $197 \mathrm{~Hz}$ at $-39 \mathrm{mV}$. Further depolarization resulted in a damping of the ringing response. The nominal ringing frequency of each cell was taken from that response in which the greatest number of peaks could be resolved. This is equivalent to the oscillation with the highest $Q$ (Crawford and Fettiplace, 1981). The membrane potential where this occurred was always several millivolts positive to the resting potential of the cell. As in turtle (Crawford and Fettiplace, 1981) and frog (Pitchford and Ashmore, 1987) hair cells, the very highest frequency oscillations in a cell did not have the highest $Q$. For 8 well-characterized basal cells, the ringing frequency during a small depolarizing step ranged from 100 to $248 \mathrm{~Hz}$ (mean, $181 \mathrm{~Hz}$ ) at room temperature. A slow after-hyperpolarization was usually seen following the depolarizing step, after which the baseline noise resumed. Symmetrical on- and off-ringing was not seen in any basal cells.

\section{Ionic currents in basal cells}

Ionic currents that might contribute to voltage ringing were investigated by voltage clamping the hair cells. In each case the cell was held at $-54 \mathrm{mV}$, near the membrane potential where oscillations occurred, and depolarizing and hyperpolarizing voltage steps werc imposed. Net ionic currents rccorded in voltage clamp of the cell in Figure $2 A$ are shown in Figure $2 B$. Capacitive and leakage currents generated during equivalent negative steps (seen in the lower record) were subtracted from net current generated during positive steps. The ionic currents generated by depolarization consisted of a small inward current that activated within $1 \mathrm{msec}$, followed by a considerably larger, maintained outward current whose initial rate of rise increased with increasing depolarization. These outward currents were probably carried by $\mathrm{K}$, since tail currents reversed near -80 $\mathrm{mV}$ in other cells. Further evidence that the outward current was carried by $K$ came from experiments using the $K$ channel blocker TEA and from replacement of internal $\mathrm{K}$ with $\mathrm{Cs}$. Half the outward current was blocked by $0.5 \mathrm{~mm}$ TEA (not shown) and outward current was totally eliminated when Cs replaced $\mathrm{K}$ inside the cell (see below).

Ionic currents generated in another basal cell are shown with the corresponding steady-state $I-V$ curve in Figure $3, A$ and $B$. The $I-V$ curve was dominated by a large, noninactivating outward current between -50 and $0 \mathrm{mV}$. The input conductance measured as the chord between -54 and $0 \mathrm{mV}$ ranged from 15 to $22 \mathrm{nS}$ for all 8 basal cells. A small amount of inward rectification negative to $-75 \mathrm{mV}$ was seen in some basal cells. Pos- 

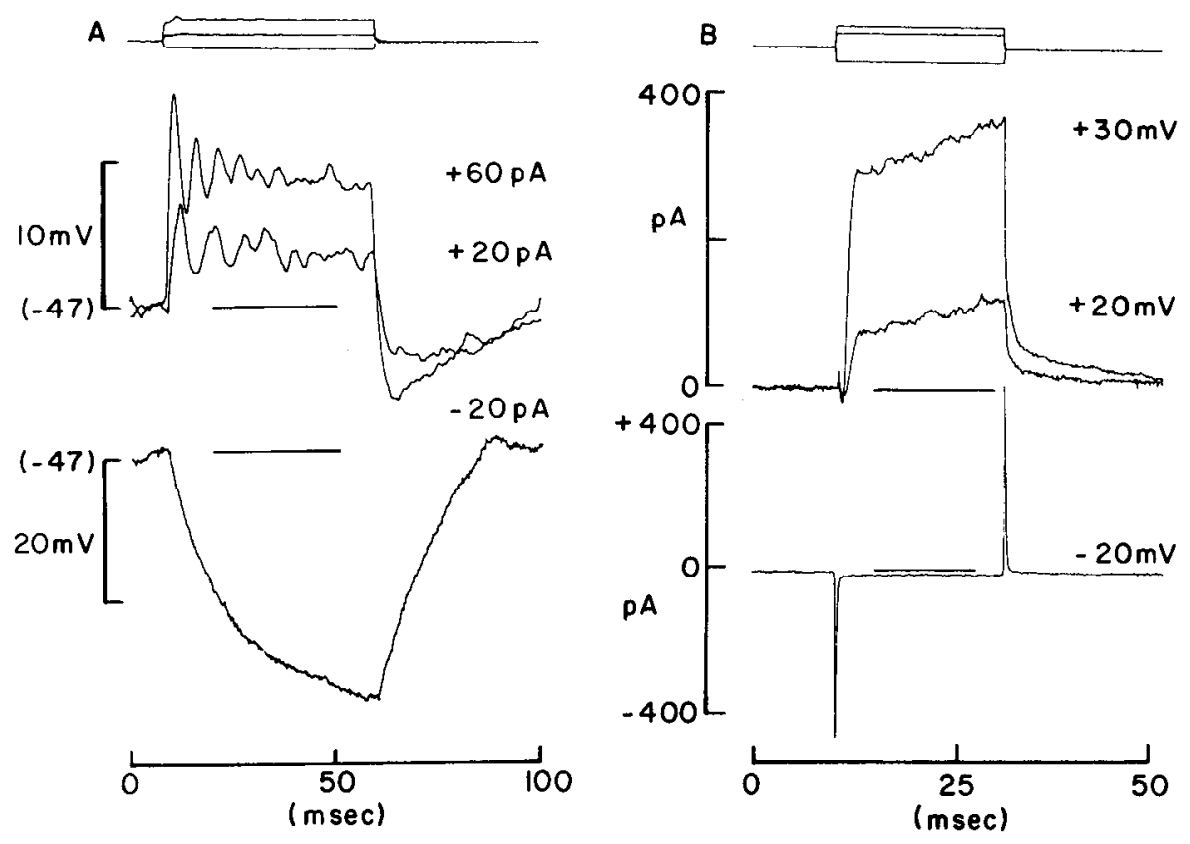

Figure 2. Voltage responses $(A)$ and membrane currents $(B)$ found in basal cells. $A$, Voltage responses were generated in an isolated basal hair cell by injected current steps of +60 and $+20 \mathrm{pA}$ (upper records) and $-20 \mathrm{pA}$ (lower record) from the resting potential of $-47 \mathrm{mV}$. During the $+20 \mathrm{pA}$ step, the cell generated a damped oscillation at $119 \mathrm{~Hz}$. During the $+60 \mathrm{pA}$ step, the cell oscillated at $197 \mathrm{~Hz}$. Both current steps were followed by large, slow after-hyperpolarizations (that following the $+60 \mathrm{pA}$ step was larger). Injection of a $-20 \mathrm{pA}$ current step produced a larger, slower voltage change. Note that the vertical gain in the lower record is one-half that in the pair of upper records. The digitization interval was $0.2 \mathrm{msec}$. B, Currents generated in the same cell by voltage steps away from a holding potential of $-54 \mathrm{mV}$. The amplitude of each step is given beside each record. Capacitive and leakage currents were removed from each of the 2 upper records by subtraction of those currents generated during an equal amplitude negative voltage command. Capacitive and leakage currents generated during a $-20 \mathrm{mV}$ voltage command are shown in the lower record. Input capacitance of the cell was $4.73 \mathrm{pF}$, and series resistance was $20 \mathrm{M} \Omega$. The indicated voltage commands are subject to a maximal series resistance error of 2 and $7 \mathrm{mV}$, respectively. This cell was located $1044 \mu \mathrm{m}$ from the apical tip and was $12 \mu \mathrm{m}$ long and $9 \mu \mathrm{m}$ wide; the stereovillar bundle was $7 \mu \mathrm{m}$ long. The digitization interval was $0.1 \mathrm{msec}$.

itive to $0 \mathrm{mV}$, the outward current diminished, resulting in an "N-shaped" $I-V$ curve, similar to that seen in cells containing large amounts of $\mathrm{K}_{\mathrm{Ca}}$ current (Meech and Standen, 1975). In such cells, depolarization near to the $\mathrm{Ca}$ equilibrium potential reduced $\mathrm{Ca}$ influx and so Ca-activated currents decreased as well, producing the $\mathrm{N}$-shaped curve.

The pronounced $\mathrm{N}$ shape of the $I-V$ curves of these basal cells implied that much of the outward current was due to activation of $\mathrm{K} \mathrm{K}_{\mathrm{Ca}}$ conductance. The dependence of the outward $\mathrm{K}$ current on external $\mathrm{Ca}$ was shown directly by replacing $\mathrm{cx}$ ternal Ca with $\mathrm{Mg}$ (open symbols, Fig. $3 B$ ). The average currents produced by a $+50 \mathrm{mV}$ step hefore and during Ca-free superfusion are shown in Figure $3 C$. Virtually all the outward current was eliminated during this procedure. The effect of $\mathrm{Ca}$-free solutions was completely reversible. The outward currents in these cells were quite noisy (Fig. $3, A$ and $D$ ), suggesting that the underlying single-channel conductance was relatively large.

Inward currents were examined in basal cells by blocking the larger outward currents. This was accomplished by the external application of 10-20 mM TEA (not shown) or by recording from the cells with $\mathrm{Cs}$-filled pipettes, thus replacing the internal $\mathrm{K}$ with an impermeant cation. An example of the effect of Cs loading of a basal cell is shown in Figure $3 D$. Immediately upon breaking into the cell, a voltage-clamp command from -54 to $-14 \mathrm{mV}$ evoked a small early inward current followed by a larger, maintaincd outward current. Within $10 \mathrm{sec}$ the outward current was abolished, leaving a maintained inward current. This maintained inward current was a Ca current since it required $\mathrm{Ca}$ in the extracellular medium and was also carried by
Ba ions. Thus, the major ionic currents in basal hair cells in the voltage range of -50 to $0 \mathrm{mV}$ were the inward Ca current and the outward $\mathrm{K}_{\mathrm{Ca}}$ current. The $\mathrm{K}_{\mathrm{Ca}}$ current was at least 5 times larger and so usually obscured the Ca current in recordings of net ionic current. $\mathrm{Ca}$ and $\mathrm{K}_{\mathrm{Ca}}$ currents have also been described in chick vestibular hair cells (Ohmori, 1984).

The large outward current that dominated the steady-state $I-$ $V$ relation of these cells was maintained during long depolarizations (up to $2 \mathrm{sec}$ ) and had rapid activation kinetics. The halftime to peak for outward current generated by a voltage command from -54 to $-34 \mathrm{mV}$ ranged from 0.9 to $2.35 \mathrm{msec}$. In some basal cells the outward current turned on so rapidly that no inward current was visible (Fig. 3, $A$ and $C$ ). In contrast to this relatively uniform activation rate, the time course of outward tail current decay following positive voltage commands varied nearly 50 -fold. In some basal cells the outward tails were fast, decaying in a few msec (Fig. 3, $A, C$, and $D$ ). In other cells, like that in Figure $2 B$, very slow tail currents were seen, lasting tens of milliseconds. In such cells there was also a second, slow phase of activation equivalent in its kinetics to those of the tail current. For all the basal cells the half-time of tail current decay ranged from 0.77 to $48.2 \mathrm{msec}$. The source of this variability is unknown at present. The slowly activating current formed only a small fraction of the total current during the depolarization. However, the slow component often dominated the tail current, and probably accounted for the slow after-hyperpolarization seen in cells that had high-frequency voltage oscillations during the step.

In previous studies on electrically tuned hair cells of lower 


\section{A}
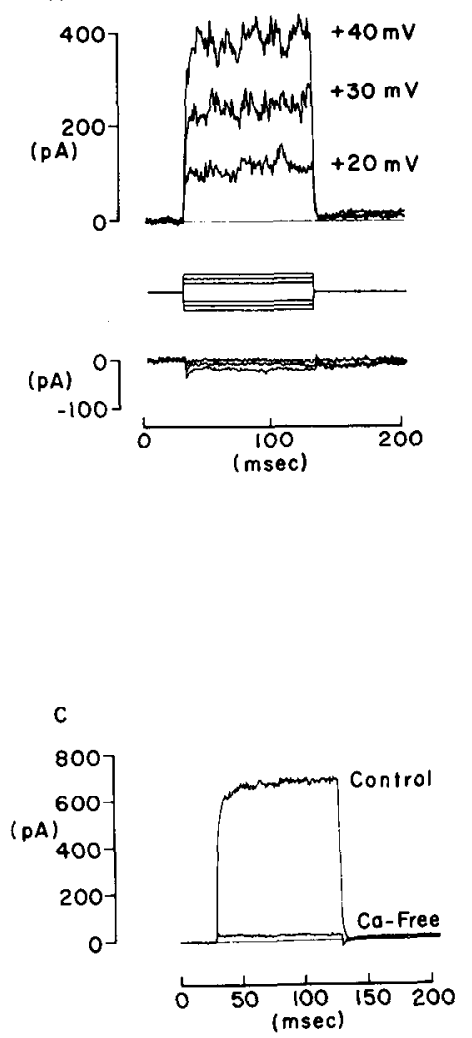
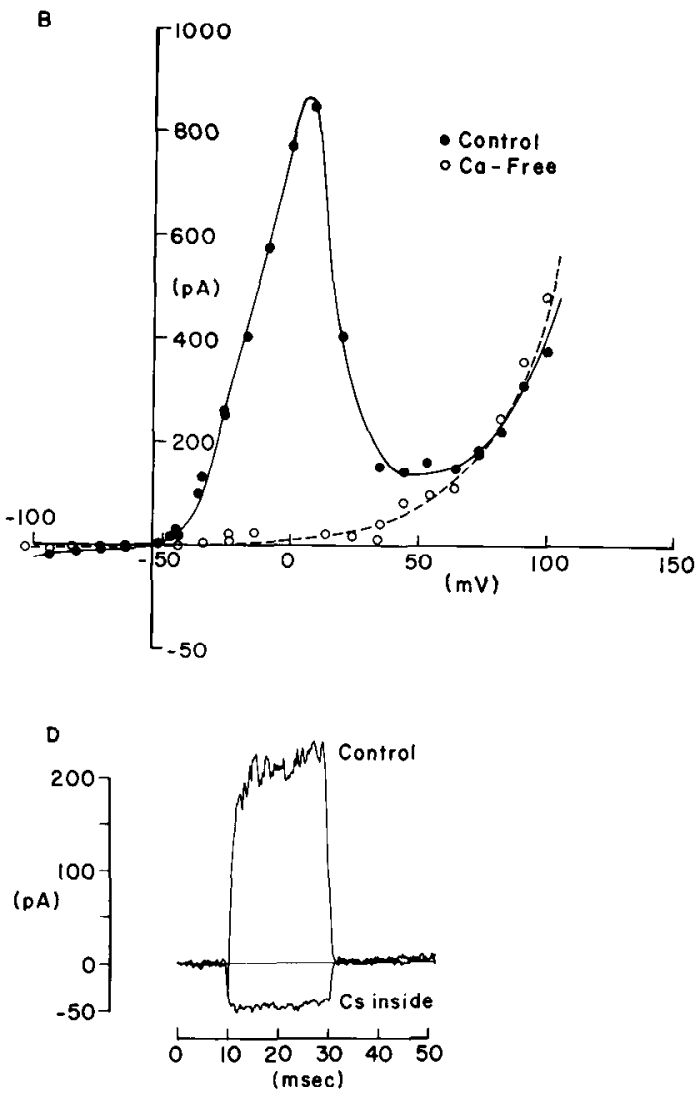

Figure 3. Ionic currents in basal cells. $A$, Net ionic currents generated in a basal cell during voltage steps of 20,30 , and $40 \mathrm{mV}$ from a holding potential of $-54 \mathrm{mV}$. During the depolarization, large, rapidly activating, noisy outward currents were seen. No inward current was seen. Negative commands of equal amplitude generated only very small currents. All current records have had leak (2.5 G $\Omega$ ) and capacitive (cell capacitance was $6.82 \mathrm{pF}$ ) currents subtracted. The digitization interval was $0.4 \mathrm{msec}$. B. The effect of Ca-free saline on the steady-state $I-V$ relation. Filled circles show the control measurements; open circles show the steady-state $I-V$ relation during superfusion of the cell with Ca-free saline. Smooth curves were drawn by eye through the points. Leakage current was subtracted, and the membrane potential was compensated for $8.5 \mathrm{M} \Omega$ series resistance. $C$, Effect of Ca-free superfusion on outward currents in the same cell as $A$ and $B$. Five current records were averaged for both the control current and the residual current during Ca-free superfusion. $D$, Effect of internal Cs perfusion on another basal cell (located $1044 \mu \mathrm{m}$ from the apical tip). A cell-attached patch was formed with a pipette containing $\mathrm{Cs}$ instead of $\mathrm{K}$. The pipette was voltage-clamped to $-53 \mathrm{mV}$, and depolarizing steps of $40 \mathrm{mV}$ were applied every $100 \mathrm{msec}$. The large outward current was recorded immediately after rupturing the membrane patch, and 10 sec later, the only current remaining was the inward current seen below. Capacitive and leakage currents have been subtracted from these records. No series resistance compensation was made. The digitization interval was $0.1 \mathrm{msec}$.

vertebrates it was found that variations in the kinetics of the outward current were correlated with the ringing frequency, or resonance frequency, of the cell (Roberts et al., 1986; Art and Fettiplace, 1987). On one occasion it proved possible to record from ringing chick hair cells isolated from 3 adjacent basal sections, centered at 1152,1404 , and $1656 \mu \mathrm{m}$ from the apical tip. The ringing frequency increased from 100 to 156 to $185 \mathrm{~Hz}$ in the 3 successively more basal cells, and the time to halfactivation of the outward current decreased from 2.35 to 1.92 to $1.36 \mathrm{msec}$, respectively. Thus, faster outward currents were found in cells with higher frequency voltage ringing, and faster cells came from successively more basal locations.

\section{Voltage response of apical cells}

In current clamp, apical cells had more negative resting potentials, averaging $-77.6 \mathrm{mV}$ ( 8 cells). There was no voltage noise or spontaneous ringing at the resting potential. When current was injected to depolarize the cell to approximately $-60 \mathrm{mV}$, large action potentials were evoked (Fig. $4 A$ ). These could overshoot $0 \mathrm{mV}$, but in other apical cells, they were as small as 30
$40 \mathrm{mV}$ peak amplitude. For longer depolarizing steps, repetitive action potentials occurred at frequencies between 5 and $10 \mathrm{~Hz}$ in different cells. With maintained depolarization to $-50 \mathrm{mV}$, repetitive action potentials were replaced by smaller amplitude, higher frequency voltage oscillations. When the cells were depolarized positive to $-25 \mathrm{mV}$, the oscillations became very small and irregular and finally disappeared. In the voltage range of -50 to $-25 \mathrm{mV}$, the average voltage response to a small current step consisted of decaying oscillations, or ringing at the onset and offset of the current step (Fig. $4 B$ ). For 8 well-characterized apical cells the ringing frequency ranged from 5 to 14 $\mathrm{Hz}$ (determined as described above for basal cells).

Thus, tall cells from the low-frequency cochlear apex exhibited voltage behavior that differed dramatically from that of basal cells. Brief depolarizations from the resting potential produced action potentials. Maintained depolarization to near -50 $\mathrm{mV}$ elicited voltage oscillations at frequencies nearly 20 -fold lower than those seen in basal cells. The low-frequency voltage behavior found in apical cells confirmed our expectations based on the origin of these cells in the cochlear apex. 
A

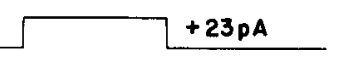

B

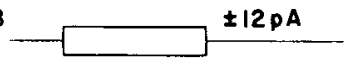

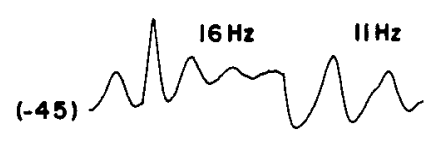
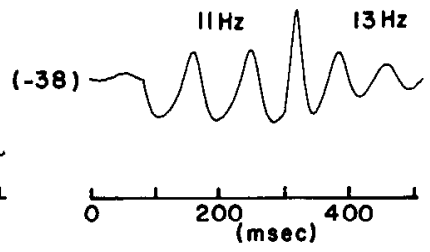

Figure 4. Voltage recording from an apical cell. $A$, Depolarizing current steps of $23 \mathrm{pA}$ caused overshooting action potentials to be generated from the resting potential of $-74 \mathrm{mV}$. When the cell was depolarized with steady current, low-frequency voltage oscillations were produced. $B$, Superposition of a $12 \mathrm{pA}$ step onto the steady current gave rise to average $(n=10)$ voltage responses such as those seen here. These consisted of decaying oscillations whose frequency and amplitude depended on the membrane potential. The depolarizing current step produced an on-ring at $16 \mathrm{~Hz}$ and an off-ring at $11 \mathrm{~Hz}$. During the hyperpolarizing step on- and off-rings were 11 and $13 \mathrm{~Hz}$, respectively. Because of the difference in membrane potential, the on-ring during the hyperpolarization occurred at the same membrane potential as did the off-ring following the depolarization, and these 2 oscillations were at the same frequency. The digitization interval was $1 \mathrm{msec}$.

\section{Ionic currents in apical cells}

Voltage-clamp recordings from the cell in Figure 4 are shown in Figure $5 A$. Although the resting potential in this cell was -79 $\mathrm{mV}$, ionic currents were activated by voltage commands away from a holding potential of $-54 \mathrm{mV}$, since this was in the voltage range in which oscillations occurred. Depolarizing commands elicited small inward currents followed by larger, noninactivating outward currents. Slow outward tail currents were seen upon return to the holding potential. Voltage commands that hyperpolarized the membrane negative to $-75 \mathrm{mV}$ elicited rapidly

Table 1. Average properties of apical and basal cells (means \pm SEM)

\begin{tabular}{|c|c|c|}
\hline Property & $\begin{array}{l}\text { Apical cclls } \\
(n=8)\end{array}$ & $\begin{array}{l}\text { Basal cclls } \\
(n=8)\end{array}$ \\
\hline Location $^{a}$ ( $\mu \mathrm{m}$ from apical tip) & $185 \pm 22$ & $1370 \pm 100$ \\
\hline Ringing frequency ${ }^{a}(\mathrm{~Hz})$ & $10.3 \pm 1.2$ & $181 \pm 22$ \\
\hline Chord conductance $^{a}(\mathrm{nS})$ & $7.2 \pm 7.0$ & $19.5 \pm 2.7$ \\
\hline $\begin{array}{l}\text { Rise time outward current }{ }^{a} \\
(\mathrm{msec})\end{array}$ & $28.4 \pm 2.1$ & $1.5 \pm 0.2$ \\
\hline $\begin{array}{l}\text { Decay time outward current }{ }^{a} \\
(\mathrm{msec})\end{array}$ & $31.8 \pm 4.1$ & $16.1 \pm 7.0$ \\
\hline Resting potential $^{n}(\mathrm{mV})$ & $77.6 \pm 2.4$ & $60.8 \pm 4.7$ \\
\hline Capacitance $(\mathrm{pF})$ & $6.4 \pm 0.4$ & $5.8 \pm 0.4$ \\
\hline Length of soma $a^{a}(\mu \mathrm{m})$ & $19.8 \pm 1.1$ & $12.7 \pm 0.4$ \\
\hline Width of soma $(\mu \mathrm{m})$ & $8.1 \pm 0.4$ & $7.9 \pm 0.3$ \\
\hline Longest stereovilli $^{a}(\mu \mathrm{m})$ & $8.5 \pm 0.2$ & $5.5 \pm 0.3$ \\
\hline
\end{tabular}

All the cells included in this table exhibited voltage ringing in current clamp. Each cell's location was taken as the distance between the midpoint of that $200 \mu \mathrm{m}$ section and the apical tip, as determined from camera lucida drawings of the isolated cochleas. Ringing frequency was measured from the highest quality ringing obtained in the voltage range -50 to $-25 \mathrm{mV}$. The chord conductance was computed from the steady-state $I-V$ curve between -54 and $0 \mathrm{mV}$. The rise time was the time at which the outward current had risen to half its steady-state value during a voltage command from -54 to $-34 \mathrm{mV}$. The decay time was the time at which the tail current had decayed to half its initial value after that same voltage command. Input capacitance was computed by dividing the integrated capacitive current by the small voltage step used to produce it. The dimensions of the hair cell were measured using a calibrated ocular micrometer in the inverted microscope; total magnification, 1600 . Cell length was measured from the base of the cell to the cuticular plate just under the middle of the hair bundle. Cell width was estimated as the average width along the length of the cell, and hair bundle height was taken as the length of the longest stereovilli.

${ }^{a}$ Two-tailed $t$ test of the means in these categories demonstrated significant differences with $p<0.005$. The average input capacitances were judged not to be significantly different, with $p>0.15$. Likewise, the average widths were not different, $p>0.4$.

activating, maintained inward currents (Fig. $5 A$, lower records). The steady-state $I-V$ relation from this cell is shown in Figure $5 B$. As in basal cells there was outward rectification in the voltage range of -50 to $0 \mathrm{mV}$. The input conductance calculated
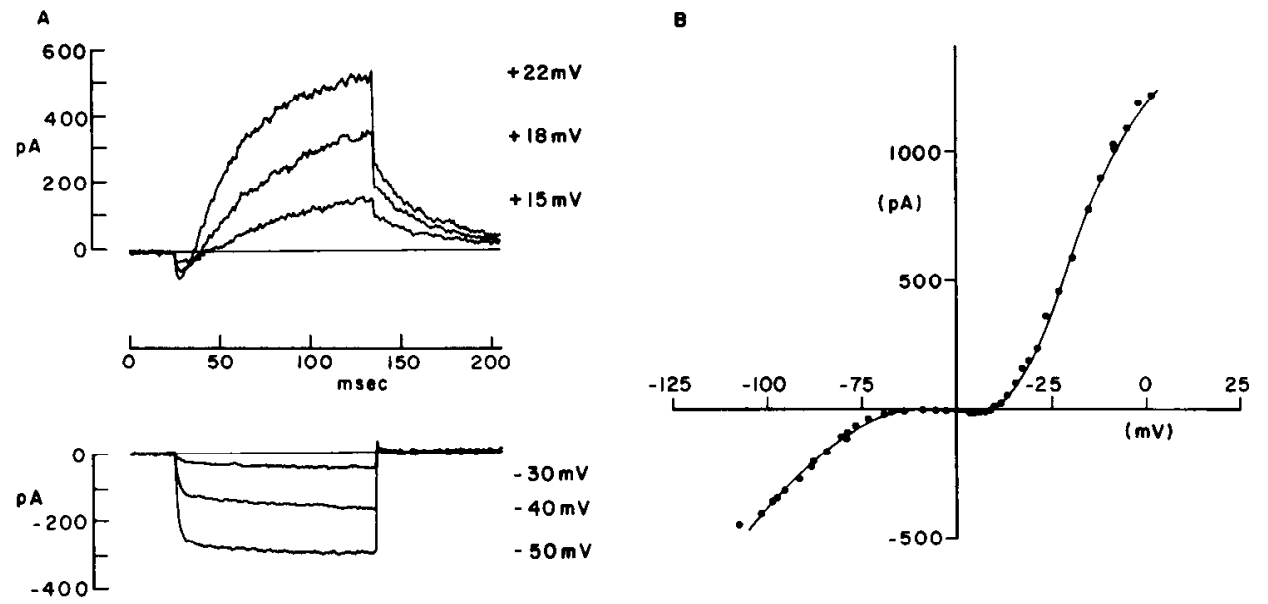

Figure 5. Membrane currents in an apical cell. Voltage clamp of the cell shown in Figure 4. $A$, Total membrane current generated during positive (upper records) and negative (lower records) commands from a holding potential of $-54 \mathrm{mV}$. The command voltage is shown beside each record. Leakage and capacitive currents have been subtracted. Leak conductance was measured during small hyperpolarizing steps from $-54 \mathrm{mV}$. A correction for series resistance of $20 \mathrm{M} \Omega$ was applied to these records. Digitization interval was $0.4 \mathrm{msec}$. $B$, Steady-state $I-V$ relation of the cell shown in $A$. The smooth curve was drawn by eye through the points. Apical cells exhibited inward rectification negative to $-75 \mathrm{mV}$ and outward rectification positive to $-40 \mathrm{mV}$. In addition, a small steady inward current was often seen between -50 and $-40 \mathrm{mV}$. This cell was found 117 $\mu \mathrm{m}$ from the apical tip, its capacitance was $5.8 \mathrm{pF}$, its dimensions were $20.4 \times 7.8 \mu \mathrm{m}$, and its hair bundle length was $9 \mu \mathrm{m}$. 
from the chord between -54 and $0 \mathrm{mV}$ averaged $7.2 \mathrm{nS}$ for the 8 apical cells. In contrast to basal cells, there was a small net inward current between -50 and $-40 \mathrm{mV}$ and pronounced inward rectification at voltages negative to approximately -75 $\mathrm{mV}$.

Preliminary evidence from experiments like those performed on basal cells suggested that a portion of the outward current was carried by $K_{\text {a }}$ channels and that the inward current seen during depolarization was a Ca current. However, approximately half of the outward current was unaffected by superfusion with $\mathrm{Ca}-$ free saline. The identity and functional role of this $\mathrm{Ca}$ insensitive outward current are presently under investigation.

Outward currents in apical cells activated slowly (e.g., Fig. $5 A$, upper records). The half-time to peak activation ranged from 22 to $37 \mathrm{msec}$ for outward current activated by a step from -54 to $-34 \mathrm{mV}$. The half-decay time of tail current ranged from 19 to $55 \mathrm{msec}$. There was reasonable agreement between the rates of activation and decay of outward current in apical cells.

\section{Discussion}

Comparison of basal and apical cells

We examined tall hair cells from 2 widely separated regions of the chick cochlea. Apical cells had hair bundles that were longer than those of basal cells (average values: $8.5 \mu \mathrm{m}$, apical cells; $5.5 \mu \mathrm{m}$, basal cells), as predicted by previous work carefully documenting the gradient of decreasing stereovillar length from apex to base in the cochlea (Tilney and Saunders, 1983). The bundle lengths reported here are longer than those given previously (apical bundles were found to be $5.5 \mu \mathrm{m}$ long), but this difference may result from the present measurements being made on living tissue not subject to shrinkage during fixation.

Apical cells were longer than basal cells (19.8 vs $12.7 \mu \mathrm{m}$ average length of soma). Since tall cells were more difficult to isolate from basal sections, and there is a greater proportion of short cells in basal sections, our average differences in length may arise from a selection bias toward shorter cells in basal sections. However, we always recorded from the tallest available cells, so this difference may imply that all hair cells get shorter along the apical to basal axis (von During et al., 1985).

Soma width and input capacitance did not differ significantly between apical and basal cells. These comparisons are perhaps surprising since the dimensions listed here would lead one to expect significant differences in surface area and, therefore, capacitance. However, input capacitance may not be directly comparable with these estimates of soma membrane area since the contribution of the stereovillar bundle to the total membrane area has been ignored. Basal cells have a larger number of stereovilli than do apical cells (Tilney and Saunders, 1983), and this factor will help to equalize input capacitance in cells whose somatal surface areas differ.

Average resting potentials were $17 \mathrm{mV}$ more negative in apical cells than in basal cells (means of -77.6 and $-60.8 \mathrm{mV}$ ). The resting potentials of basal cells were nearer to those found in clectrically tuned hair cells of turtles ( $-50 \mathrm{mV}$ : Art and Fettiplace, 1987) and frogs ( -58 to $-65 \mathrm{mV}$ : Lewis and Hudspeth, 1983). In both apical and hasal cells the resting potentials found in this study may be significantly more negative than those of cells in vivo. In the process of isolation the fragile transduction mechanism may be damaged and any standing inward current through those channels eradicated. This effect is likely to be more pronounced in apical cells, since the inward rectifier cur- rent in these cells would also contribute to the resulting hyperpolarization.

Repetitive action potentials could be evoked in apical cells by depolarization positive to $-65 \mathrm{mV}$, and when cells were depolarized to $-50 \mathrm{mV}$, low-frequency voltage ringing occurred. In basal cells, high-frequency voltage ringing could be evoked by small depolarizations from the resting potential, and action potentials were never seen. These differences in voltage behavior must result from the different ionic currents found in these 2 groups of cells. Net outward currents in basal cells activated nearly 20 times more rapidly than did those in apical cells (average half-rise time, 1.50 vs $28.4 \mathrm{msec}$ ). In addition, basal cell outward currents were nearly 3-fold larger on average. Similar variations in outward currents were found to underlie the variability in electrical tuning of turtle and frog hair cells. Cells with higher frequency voltage oscillations had larger, more rapidly activating $\mathrm{K}_{\mathrm{Ca}}$ currents (Roberts et al., 1986; Art and Fettiplace, 1987). It is possible, then, that the high-frequency ringing found in basal cells and much lower frequency ringing found in apical cells arises from the varied characteristics of their outward currents. It is unclear, however, whether these kinetic differences in chick hair cells can be attributed solely to modulation of $\mathrm{K}_{\mathrm{Ca}}$ current as in lower vertebrates. There appears to be more than one type of outward current in chick hair cells. The outward current of apical cells includes a significant $\mathrm{Ca}$ insensitive component. The outward current in some basal cells can also include a smaller, much slower component that may underlie the slow after-hyperpolarization seen following depolarization. It will be of considerable interest to determine whether these kinetic differences both between cells and within a single cell can be assigned to onc or several types of $\mathrm{K}$ channcl.

The ability of apical cells to generate action potentials must derive from the greater net inward current found in voltage clamp. The slowly activating outward current in apical cells permits considerably longer-lasting net inward current and, therefore, generation of action potentials. The fast, large outward currents in basal cells prevent such a regenerative depolarization.

\section{Role of electrical tuning in the chick}

The membrane properties of hair cells from basal regions of the chick cochlea were strikingly similar to those of electrically tuned hair cells in lower vertebrates. This similarity suggests that electrical tuning may play a role in the frequency selectivity of the chick cochlea. Further insight into the functional significance of these results can be gained by comparison with previous studies on the frequency dependence of basilar membrane vibration in the chick. For electrical tuning to play a functional role it should correspond with the mechanical input to the cell. To make this comparison it must first be noted that these recordings on isolated cells were made at room temperature, nearly $20^{\circ} \mathrm{C}$ cooler than the internal temperature of the chick. Studies on the temperature dependence of auditory nerve fiber tuning in birds revealed an octave change in best frequency for each $10^{\circ} \mathrm{C}$ (Schermuly and Klinke, 1985), and quantitatively similar effects of temperature were observed on the frequency of voltage ringing in isolated apical cells (P.A.F., unpublished observations). With this correction for temperature, basal cell ringing frequencies would range from 0.4 to $1.0 \mathrm{kHz}$, thus corresponding well with the frequency maxima found for this region $(0.3-1.0 \mathrm{kHz})$ in studies of basilar membrane vibration (von Bekesy, 1960). 
The membrane properties of hair cells from the cochlear apex were less like those of other electrically tuned cells, and more like those of vestibular hair cells of the chick, particularly with regard to the presence of inward rectifier current (Ohmori, 1984). The resting potential of apical cells was far below the voltage range in which ringing occurred, and if these same resting potentials occur in vivo, sounds of moderate intensity would be more likely to elicit action potentials, rather than voltage ringing, from these cells. Nonetheless, action potentials were repetitive at low frequencies, and the apical cells' membrane kinetics would be appropriate for low-frequency sound detection, which occurs in the cochlear apex. It is of interest that an analogous population of cells from the morphologically similar alligator cochlea also generates action potentials (Evans and Fuchs, 1987). In alligator hair cells, however, a voltage-dependent $\mathrm{Na}$ current contributes to action potential generation.

Anatomical studies of the apical tip of the chick cochlea led to the postulate that hair cells here might differ in their functional role from that of the rest of the cochlea (Lavigne-Rebillard et al., 1985). In particular, their morphological similarity to lagenar (vestibular) hair cells was noted, and it was suggested that they may serve in the detection of ultra-low-frequency sound (Yodlowski et al., 1977; Theurich et al., 1984).

The present results suggest that variations in the properties of ionic currents of hair cells could play a role in the frequency selectivity of the chick cochlea. Such electrical tuning accounts in large part for the lower frequency hearing of the turtle (Crawford and Fettiplace, 1981). The chick cochlea may attain its expanded frequency range through a combination of electrical and mechanical tuning and offers an opportunity to evaluate the contribution of each mechanism as a function of stimulus frequency.

\section{References}

Art, J. J., and R. Fettiplace (1987) Variation of membrane properties in hair cells isolated from the turtle cochlea. J. Physiol. (Lond.) 385: 207-242.

A.shmore, J. F. (1983) Frequency tuning in a frog vestibular organ. Nature 304: 536-538.

Crawford, A. C., and R. Fettiplace (1981) An electrical tuning mechanism in turtle cochlear hair cells. J. Physiol. (Lond.) 312: 377-412.

Dooling, R. J. (1980) Behavior and psychophysics of hearing in birds. In Comparative Studies of Hearing in Vertebrates, A. N. Popper and R. R. Fay, eds., pp. 261-288, Springer-Verlag, New York.

Evans, M. G., and P. A. Fuchs (1987) Tetrodotoxin-sensitive, voltagedependent sodium currents in hair cells from the alligator cochlea. Biophys. J. 52: 649-652.

Fuchs, P. A., and A. C. Mann (1986) Voltage oscillations and ionic currents in hair cells isolated from the apex of the chick's cochlea. J. Physiol. (Lond.) 371: 31P.

Gleich, O. (1987) Electrical tuning in the avian inner ear. Abstracts of the Midwinter Meeting, Association for Research in Otolaryngology, Clearwater Beach, FL, p. 22.
Gummer, A. W., J. W. T. Smolders, and R. Klinke (1987) Basilar membrane motion in the pigeon measured with the Mossbauer technique. Hearing Res. 29: 63-92.

Hirokawa, N. (1978) The ultrastructure of the basilar papilla of the chick. J. Comp. Physiol. 181: 361-374.

Lavigne-Rebillard, M., H. Cousillas, and R. Pujol (1985) The very distal part of the basilar papilla in the chicken: A morphological approach. J. Comp. Neurol. 238: 340-347.

Lewis, R. S., and A. J. Hudspeth (1983) Voltage- and ion-dependent conductances in solitary vertebrate hair cclls. Naturc 304: 538-540.

Manley, G. A. (1979) Preferred intervals in the spontaneous activity of primary auditory neurones. Naturwissenschaften $66: 582$.

Manley, G. A., O. Gleich, H.-J. Leppelsack, and H. Oeckinghaus (1985) Activity patterns of cochlear ganglion neurones in the starling. $J$. Comp. Physiol. 157: 161-181.

Marty, A., and E. Neher (1983) Tight-seal whole-cell recording. In Single Channel Recording, B. Sakmann and E. Neher, eds., pp. 107122, Plenum, New York.

Meech, R. W., and N. B. Standen (1975) Potassium activation in Helix aspersa neurones under voltage clamp: A component mediated by calcium influx. J. Physiol. (Lond.) 249: 211-239.

Ohmori, H. (1984) Studies of ionic currents in the isolated vestibular hair cell of the chick. J. Physiol. (Lond.) 350: 561-581.

Pitchford, S., and J. F. Ashmore (1987) An electrical resonance in hair cells of the amphibian papilla of the frog Rana temporaria. Hearing Res. 27: 75-83.

Roberts, W. M., L. Robles, and A. J. Hudspeth (1986) Correlation between the kinetic properties of ionic channels and the frequency of membrane-potential resonance in hair cells of the bullfrog. In Auditory Frequency Selectivity, B. C. J. Moore and R. D. Patterson, eds., pp. 89-96, Plenum, New York.

Rubel, E. W. (1978) Ontogeny of structure and function in the vertebrate auditory system. In Handbook of Sensory Physiology, Development of Sensory Systems, Vol. 9, M. Jacobsen, ed., pp. 135-237, Springer, New York.

Sachs, M. B., E. D. Young, and R. H. Lewis (1974) Discharge patterns of single fibers in the pigeon auditory nerve. Brain Res. 70:431-447.

Schcrmuly, L., and R. Klinkc (1985) Changc of charactcristic frcquency of pigeon primary auditory afferents with temperature. J. Comp. Physiol. 156: 209-211.

Tanaka, K., and C. A. Smith (1978) Structure of the chicken's inner ear: SEM and TEM study. Am. J. Anat. 153:251-272.

Theurich, M., G. Langner, and H. Scheich (1984) Infrasound responses in the midbrain of the guinea fowl. Neurosci. Lett. 49: 81-86.

Tilney, L. G., and J. C. Saunders (1983) Actin filaments, stereocilia, and hair cells of the bird cochlea. I. Length, number, width, and distribution of stereocilia of each hair cell are related to the position of the hair cell on the cochlea. J. Cell. Biol. 96: 807-821.

Tilney, L. G., and M. S. Tilney (1986) Functional organization of the cytoskeleton. Hearing Res. 22: 55-77.

von Bekesy, G. (1960) Experiments in Hearing, pp. 504-506, McGraw-Hill, Ncw York.

von During, M., K. H. Andres, and K. Simon (1985) The comparative anatomy of the basilar papillae in birds. In Functional Morphology in Vertebrates, H.-R. Duncker and G. Fleischer, eds., pp. 682-685, Gustav Fischer Verlag, Stuttgart.

Yellen, G. (1982) Single Ca-activated nonselective cation channels in neuroblastoma. Nature 296: 357-359.

Yodlowski, M. L., M. L. Kreithen, and W. T. Keeton (1977) Detection of atmospheric infrasound by homing pigeons. Nature 265: 725-726. 